\title{
USH1G Gene
}

National Cancer Institute

\section{Source}

National Cancer Institute. USH1G Gene. NCI Thesaurus. Code C114406.

This gene plays a role in both sight and hearing. 